\title{
A PROIBIÇÃO DE DISCRIMINAÇÃO NOS CONTRATOS NO DIREITO BRASILEIRO EM FACE DA EXPERIÊNCIA EUROPEIA ${ }^{1}$
}

\author{
THE PROHIBITION OF DISCRIMINATION IN CONTRACTS IN \\ BRAZILIAN LAW IN THE FACE OF EUROPEAN EXPERIENCE
}

\author{
ROSALICE FIDALGO PINHEIRO ${ }^{2}$
}

\begin{abstract}
RESUMO: Este trabalho tem por objetivo estabelecer um diálogo entre a experiência europeia e o Direito brasileiro acerca da proibição de discriminação no contrato. Trata-se de buscar mecanismos de correção do exercício da liberdade contratual em face dos direitos fundamentais. No direito europeu, um conjunto de diretivas delineia o princípio da proibição de discriminação no Direito Privado. Neste contexto, destaca-se sua recepção pelos Estados membros da União Europeia, por meio da Lei Geral de Igualdade de Tratamento, no direito alemão, e por meio de leis especiais, no direito espanhol. No direito brasileiro, acentua-se o papel hermenêutico do intérprete, que encontra no direito à igualdade de tratamento, previsto no artigo $5^{\circ}$, caput, e artigo $3^{\circ}$, IV, da Constituição da República, uma norma de eficácia imediata nas relações interprivadas para concretizar o direito à diferença e uma cidadania efetiva. Propõe-se, ainda, investigar o tema na jurisprudência brasileira que enseja uma proteção mitigada contra discriminação no contrato, revelando a liberdade contratual e a autonomia privada afetas aos seus contornos clássicos. Para tanto, o trabalho utiliza-se da análise de casos concretos e do procedimento bibliográfico, para submeter o direito brasileiro a uma reflexão crítica sobre o tema da discriminação no contrato.

PALAVRAS-CHAVES: Discriminação; Contrato; Direito à Igualdade de Tratamento; Experiência Europeia.
\end{abstract}

\footnotetext{
Artigo recebido em 31.03.2014. Pareceres emitidos em 18.08.2014 e 29.08.2014.

Artigo aceito para publicação em 06.10.2014.

${ }^{1}$ Artigo apresentado no Seminário "Igualdad y protección contra la discriminación en el Derecho Privado", realizado nos días 22, 23 e 24 de janeiro de 2014, no Programa Master Oficial en Derecho Patrimonial Privado en el Mercado Global (El Nuevo Derecho Europeo de Contratos), da Universidad Pablo de Olavide, em Sevilha, Espanha, mediante auxílio financeiro do Programa PAEX/CAPES n $12.729-13-2$.

${ }^{2}$ Doutora e Mestre em Direito das Relações Sociais junto ao Programa de Pós-graduação em Direito da Universidade Federal do Paraná (Curitiba). Professora Adjunta de Direito Civil do Setor de Ciências Jurídicas da Universidade Federal do Paraná (Curitiba). Professora e Coordenadora do Programa de Mestrado em Direito das Faculdades Integradas do Brasil. Curitiba, Paraná. rosallice@gmail.com
} 
ABSTRACT: This work has the objective to establish a dialogue between European experience and Brazilian Law about the prohibition of discrimination in contract law. It is to find mechanisms to correction the exercise of liberty of contract in the face of fundamental rights. In European Law, a set of directives delineates the principle of prohibition of discrimination in Private Law. In this context, stands out its receipt by Member States of the European Union, by the General Equal Treatment Act German Law, and by special laws, in Spanish Law. In Brazilian Law, is accentuated the hermeneutical role of the interpreter, who finds in the right to equal treatment law, laid down in Article 5, caput, and Article 3, IV, of the Constitution, a rule of immediate effectiveness in private relationships to materialize the right to be different and effective citizenship. Proposes to also investigate the theme under Brazilian Law that provides mitigated protection against the discrimination in the contract, showing liberty of contract and liberty affects its classic contours. For this purpose the work makes use of analysis of case law and bibliographical procedure to submit the Brazilian Law to a critical reflection on the theme of discrimination in the contract.

KEYWORDS: Discrimination; Contract; Right to Equal Treatment; European Experience.

SUMÁRIO: Introdução; 1. Autonomia Privada e Discriminação; 2. A Experiência Europeia: o princípio da não discriminação no Direito Privado; 3. O Direito Fundamental à Igualdade de Tratamento e a Proteção contra Discriminação no Contrato no Direito Brasileiro; 4. Contornos da Liberdade Contratual em Face da Proibição de Discriminação na Jurisprudência Brasileira; Considerações Finais; Referências.

INDEX: Introduction; 1. Liberty and Discrimination; 2. The European Experience: the principle of non-discrimination in Private Law; 3. The Fundamental Right to Equal Treatment of Law and Protection against Discrimination in the Brazilian Contract Law; 4. Contours of Liberty of Contract in the Face of the Prohibition of Discrimination under Brazilian Case Law; Final Considerations; References.

\section{INTRODUÇÃO}

O avanço da globalização econômica em uma sociedade multicultural como a brasileira, não parece suscitar dificuldades acerca da inclusão do outro, quando está em jogo o exercício das liberdades econômicas.

Paradoxalmente, esta constatação é afastada por casos de discriminação que chegam aos tribunais brasileiros: (i) em contratos de plano de saúde as operadoras determinam reajustes das mensalidades, em face da alta sinistralidade representada por usuários idosos; (ii) em contratos de seguro com cláusula perfil do segurado, os prêmios se elevam em razão da idade ou sexo do segurado; (iii) nos contratos de financiamento habitacional, a bonificação concedida aos deficientes físicos para aquisição da casa própria é dissipada pela onerosidade do prêmio, ou, até mesmo, pela recusa da proposta de seguro em face da condição física do segurado, inviabilizando a concessão do crédito. Tais situações revelam, no plano axiológico, uma tensão entre os princípios da liberdade contratual e da igualdade de tratamento, ${ }^{3}$ impondo a proteção contra discriminação no contrato no Direito brasileiro.

\footnotetext{
${ }^{3}$ RUIZ, Francisco Infante. Igualdad, Diversidad y Protección contra la Discriminación en el Derecho Privado. In: MARRERO, Carolina Mesa (coord.). Mujeres, Contratos y Empresa desde la Igualdad de Género. Valencia: Tirant lo Blanch, 2013. p. 191-250, p. 194.
} 
A proteção contra discriminação expressa um mecanismo de correção dos desequilíbrios do poder contratual, ${ }^{4}$ delineando o princípio da igualdade como direito à diferença no Direito Privado. Trata-se de depositar no "direito da diversidade" um conjunto de valores e princípios de respeito aos sujeitos de direito, não obstante as situações diversas em que se encontram. ${ }^{5}$ Busca-se uma cidadania efetiva, concretizando direitos fundamentais nas relações interprivadas.

No âmbito do Direito europeu, tal proteção já se fazia presente nas diretivas contra discriminação em razão do sexo no Direito do Trabalho, desde 1975. Porém, referidas diretivas, conjugadas a alguns pronunciamentos do Tribunal de Justiça das Comunidades, não ofereciam mais do que uma proteção mitigada. Somente com o processo de integração europeia, no final da década de noventa, um conjunto de diretivas promoveu a proibição de comportamentos discriminatórios, abrangendo a educação, a saúde, a assistência social, o acesso ao crédito e serviços e à moradia, para além dos contratos de trabalho. A incorporação destas diretivas ao Direito interno dos Estados da União Europeia teceu um "novo direito antidiscriminatório", inaugurando o último baluarte do sistema de garantias jurídicas que perde espaço para os imperativos da economia. ${ }^{6}$

Voltar as atenções para a experiência europeia e suscitar um diálogo com o Direito brasileiro é o objetivo deste trabalho. Eis que no cenário jurídico nacional, enquanto o Direito do Trabalho empreende intensa discussão sobre o tema, as situações acima descritas, encontradas nos tribunais brasileiros, parecem não despertar a atenção dos civilistas. Constata-se, portanto, uma lacuna quando se indaga acerca da existência de um princípio de proibição de discriminação no Direito Privado nacional. Embora a Constituição da República de 1988 ofereça instrumentos para afastar a discriminação no Direito Privado, a jurisprudência oferece uma proteção mitigada, que ainda mantém incólume a soberania da liberdade contratual e da automonia privada, em suas acepções clássicas.

Em atenção a esta ordem de ideias, indaga-se acerca da existência de um princípio de proibição de discriminação no Direito Privado brasileiro, à semelhança ao Direito europeu. No Direito espanhol o tema tem sido objeto de pesquisa por Francisco Infante Ruiz, ${ }^{7}$ enunciando o direito antidiscriminatório. No Direito brasileiro, Jorge Cesa Ferreira da Silva recolhe influências do Direito alemão, em um dos escassos estudos sobre o tema. ${ }^{8} \mathrm{O}$ presente trabalho

\footnotetext{
${ }^{4}$ RUIZ, Igualdad, Diversidad..., p. 201.

${ }^{5}$ RUIZ, Igualdad, Diversidad..., p. 191-192.

${ }_{7}^{6}$ RUIZ, Igualdad, Diversidad..., p. 196-201.

${ }^{7}$ RUIZ, Francisco Infante. El Desarrollo de la Prohibición de no Discriminar en el Derecho de Contratos y su Consideración en la Jurisprudencia. Revista de Derecho Patrimonial, Santiago de Chile, $\mathrm{n}^{\circ}$ 30, jan. 2013, p. 1-30.

${ }^{8}$ SILVA, Jorge Cesa Ferreira da. A Proteção contra Discriminação no Direito Contratual Brasileiro. MONTEIRO, António Pinto; NEUNER, Jörg; SARLET, Ingo Wolfgang (org.). Direitos Fundamentais e Direito Privado. Uma Perspectiva de Direito Comparado. Coimbra: Almedina, 2007, p. 389-416.
} 
vale-se destes marcos teóricos, sob o espectro de um método dedutivo, combinado com a investigação dos casos concretos, e de um procedimento de pesquisa bibliográfico, para submeter o ordenamento jurídico e a jurisprudência brasileira a uma reflexão crítica sobre o tema da proteção contra discriminação no contrato.

Os resultados alcançados pela presente pesquisa seguem um plano de trabalho que se divide em quatro partes: inicialmente, contrapõe-se (i) "autonomia privada e discriminação", com vistas a indagar se "tratar distintamente" faz parte da essência daquele princípio ou importa em violação aos direitos fundamentais; em seguida, volta-se as atenções para (ii) "a experiência europeia: o princípio da não discriminação no Direito Privado", delineando um conjunto de diretivas que adentram no Direito interno dos Estados europeus, ensejando o princípio de proibição de discriminação nas relações interprivadas; (iii) "o direito fundamental à igualdade de tratamento e a proteção contra discriminação no contrato no Direito brasileiro" despertam o papel hermenêutico do intérprete, com vistas a conter os casos de discriminação; em face da proteção contra discriminação na experiência europeia, enfrenta-se o tema nos tribunais, a fim de traçar, criticamente, os (iv) "contornos da liberdade contratual em face da proibição contra discriminação na jurisprudência brasileira".

\section{AUTONOMIA PRIVADA E DISCRIMINAÇÃO}

Traduzida como "pedra angular" do Direito Privado, a autonomia privada é um princípio político, ${ }^{9}$ que tem seus limites delineados pelas transformações do Estado. A ruptura com o sistema feudal e um regime de incapacidades que aprisionavam o homem, rendeu-lhe o aspecto de uma liberdade extremamente ampla, capaz de ensejar a passagem para uma forma superior de sociedade, ${ }^{10}$ desenhando a "hipertrofia da autonomia da vontade". ${ }^{11}$ Neste momento histórico, o Direito foi chamado a fazer da liberdade individual e da igualdade parente a lei a mais alta realização da personalidade do indivíduo. Caracteriza-se a autonomia privada como um princípio fundamental do Direito Privado, que permite ao homem afirmar-se como pessoa. ${ }^{12}$

Os contornos desse princípio são inscritos sob os postulados de uma nova ordem política. No Estado de Direito Liberal a dicotomia público e privado

\footnotetext{
${ }^{9}$ FACHIN, Luiz Edson. Novo Conceito de Ato e Negócio Jurídico. Curitiba: Educa; Scientia et Labor, 1988, p. 58.

${ }_{10}$ ROPPO, Enzo. O Contrato. Tradução de Ana Coimbra e M. Januário C. Gomes. Coimbra: Almedina, 1988, p. 37.

${ }^{11}$ ROMAIN, Jean-François. Théorie Citique du Principe Général de Bonne foi em Droit Privé. Des atteintes à la bonne foi, en général, et de la fraude, en particulier (fraus omnia corrumpit) Bruxelles: Bruylant, 2000, p. 138-139.

${ }^{12} \mathrm{Tal}$ ideia torna-se presente na essência do princípio, que se define, segundo Ana Prata, como o "poder reconhecido pela ordem jurídica ao homem, prévia e necessariamente qualificado como sujeito jurídico, de juridicizar a sua atividade (designadamente, a sua atividade econômica), realizando livremente negócios jurídicos e determinando os respectivos efeitos." (PRATA, Ana. A Tutela Constitucional da Autonomia Privada. Coimbra: Almedina, 1982, p. 11)
} 
garante a não intervenção do Estado na sociedade. Reserva-se à Constituição a tarefa de regular a ordem estatal, e ao Código Civil a regulação da ordem social e econômica, dissipando-se o mundo da insegurança gerado pela multiplicidade de estatutos jurídicos do medievo por um novo padrão de juridicidade, inscrito pelo princípio da legalidade: a previsibilidade. O Código toma o lugar da Constituição avocando para si o papel de tutela dos direitos fundamentais como a "verdadeira Constituição do ideário liberal". ${ }^{13}$

Histórica e ideologicamente ligada à perspectiva individualista, a autonomia privada retratou o sujeito de direito abstrato, depositando sua vontade no centro do ordenamento jurídico. ${ }^{14}$ Neste cenário, ela se mostra como a voz das mercancias, em harmonia com o sistema capitalista, eis que o Direito Privado moderno não se importou com o homem concreto. Revestido do status de pessoa, o homem é tão somente o titular de direitos subjetivos, as vozes que figuram por trás das mercadorias, as vontades que repousam nos polos das relações jurídicas.

Identificada à liberdade econômica, a autonomia privada cumpre com uma "função translativa-circulatória", ${ }^{15}$ entrelaçando a estática e a dinâmica patrimonial. Por outras palavras, aquele princípio encontra no direito subjetivo e no negócio jurídico os veículos de sua realização. Para tanto, o contrato afirma-se como uma versão paradigmática de troca de bens, de tal modo, que a dinâmica contratual coincide com a dinâmica da autonomia privada. ${ }^{16}$ Com amparo em Enzo Roppo, é possível sustentar que a "ideologia da liberdade de contratar e da igualdade dos contratantes" esteve presente na primeira codificação brasileira, ${ }^{17}$ delineando o contrato como uma operação absolutamente livre aos contraentes, cujos limites à sua liberdade são reconhecidos em estreita medida, não cogitando de qualquer vinculação positiva, delineando a justiça contratual.

Essa concepção de autonomia privada logo se mostrou insuficiente diante de um redesenho das relações entre Estado e sociedade no Direito brasileiro. As exigências impostas pela produção em massa, a formação de monopólios, a concentração do capital e os conflitos entre empresários e trabalhadores exigiriam uma nova postura política em relação à sociedade. Rompem-se as barreiras entre o público e o privado, e o Código Civil perde o lugar de "Constituição do Direito Privado", em face da legislação setorial. O Estado move-se em duas direções: no plano econômico, busca corrigir os desvios do mercado, e no plano social, busca integrar os excluídos do tecido social. ${ }^{18}$

\footnotetext{
${ }^{13}$ CORTIANO JR., Eroulths. O Discurso Jurídico da Propriedade e suas Rupturas. Uma Análise do Ensino do Direito de Propriedade. Rio de Janeiro: Renovar, 2002, p. 69.

${ }^{14}$ PERLINGIERI, Pietro. II Diritto Civille nella Legatlità Constituzionale. Napoli: Edizioni Scientifiche Italiane, 1991, p. 137.

${ }^{15}$ BARCELLONA, Pietro. Diritto Privato e Società Moderna. Napoli: Jovene Editore, 1996, p. 320.

${ }^{16}$ BARCELLONA, op. cit., p. 324.

${ }^{17}$ ROPPO, op. cit., p. 32-35.

${ }^{18}$ BARCELLONA, op. cit., p. 103-104.
} 
Por conseguinte, o Estado de Direito se desfaz da adjetivação liberal, para se revelar como Social e Democrático, transmutando-se em Estado de direito material. ${ }^{19}$

Ao trazerem consigo o "projeto de uma nova sociedade", ${ }^{20}$ as constituições inscrevem em seus textos os princípios de Direito Privado. No âmbito da Constituição da República do Brasil de 1988, deposita-se a chave de leitura da civilística contemporânea nos valores constitucionais. Proclamado entre os fundamentos do Estado Democrático de Direito, o princípio da dignidade da pessoa humana afirma-se nesta linha de orientação, congregando a unidade do ordenamento jurídico. Afastando o caráter programático dos princípios constitucionais, significativa parcela do Direito Civil brasileiro desenha um "novo humanismo", ${ }^{21}$ ao se valer da aplicabilidade direta das normas constitucionais. Defende-se a repersonalização do Direito Civil que faz do homem e seus direitos a razão de ser da regulamentação civilística. ${ }^{22}$

Nesse cenário, indaga-se acerca da relevância constitucional da autonomia privada, buscando o fundamento de sua tutela e os limites que the são traçados pela Constituição. ${ }^{23} \mathrm{~A}$ resposta que se encontra para esta indagação pode ser sintetizada na afirmação de Pietro Barcellona: "a Constituição não se ocupa da autonomia privada, mas da iniciativa econômica". ${ }^{24}$ Eis o caminho que se segue para conferir dignidade constitucional à autonomia privada: relacioná-la ao conceito de livre iniciativa econômica, delineando-lhe uma garantia indireta. ${ }^{25}$

A Constituição da República de 1988 proclama a livre iniciativa dentre os princípios do Estado Democrático de Direito (art. $1^{\circ}$ ) e a base da ordem econômica (art. 170). Contudo, a livre iniciativa acha-se funcionalizada aos valores da existência digna e da justiça social, no texto constitucional. Considerando-se que a livre iniciativa tem sua tradução no direito de propriedade e na liberdade contratual, a Constituição elege a função social da propriedade e a defesa do consumidor como princípios que orientam a livre iniciativa. Deste modo, as restrições à propriedade a ao contrato, identificam-se em larga medida com as restrições à livre iniciativa. ${ }^{26}$ Eis os parâmetros da função social da autonomia privada, traduzidos por Pietro Perlingieri:

\footnotetext{
${ }^{19}$ NOVAIS, Jorge Reis. Contributo para uma Teoria do Estado de Direito. Do Estado de Direito Liberal ao Estado Social e Democrático de Direito. Separata de: Suplemento ao Boletim da Faculdade de Direito da Universidade de Coimbra. Coimbra, v. 24, 1987, p. 226-227.

${ }^{20}$ IRTI, Natalino. L'età della Decodificazione. 4. ed., Milano: Giuffrè, 1999, p. 75.

${ }^{21}$ FIGUEIRA, Eliseu. Renovação do Direito Privado. Lisboa: Caminho, 1989, p. 108.

${ }^{2}$ CARVALHO, Orlando de. Para uma Teoria da Relação Jurídica Civil. V. 1: A teoria geral da relação jurídica - seu sentido e limites. 2. ed., atual. Coimbra: Centelha, 1981, p. 10.

${ }^{23}$ PERLINGIERI, op, cit., p. 333.

${ }^{24}$ BARCELLONA, op. cit., p. 388.

${ }^{25}$ BARCELLONA, op. cit., p. 388.

${ }^{26}$ PRATA, op. cit., p. 201.
} 
Não se pode mais discorrer sobre limites de um dogma ou mesmo sobre exceções: a Constituição operou uma reviravolta qualitativa e quantitativa na ordem normativa. Os chamados limites à autonomia, colocados à tutela dos contraentes mais frágeis, não são mais externos e excepcionais, mas, antes, internos, na medida em que são expressão direta do ato e de seu significado constitucional. $^{27}$

Quando as desigualdades substanciais entre os indivíduos revelaram a autonomia privada como o exercício de liberdades qualitativamente diversas, no plano econômico e social, aquele princípio foi colocado em causa, e sua identificação com a liberdade econômica convertida em antinomia. ${ }^{28}$ Os contornos ideológicos que a ligavam à concepção individualista de homem, foram desfeitos, e sua funcionalização resulta como uma consequência do princípio do respeito à pessoa. Trata-se de delineá-la como um direito fundamental, ${ }^{29}$ cujo poder de autodeterminação do indivíduo, que Ihe faculta contratar ou não, pressupõe a personalidade do outro contratante, que nela se reconhece.

Com efeito, a autonomia privada deve ser conciliada com o exercício de outras liberdades que compõem o Estado Democrático de Direito, como a igualdade e a solidariedade. Eis que a tutela constitucional da autonomia privada deposita seu significado axiológico na passagem da proteção ao indivíduo para a proteção à dignidade da pessoa humana. De princípio fundamental do Direito Privado, ela passa a ser uma das dimensões do livre desenvolvimento da personalidade. ${ }^{30}$

É nesse contexto, que a proteção jurídica contra discriminação ganha relevo no Direito brasileiro: indaga-se se o exercício da liberdade contratual importa em discriminação. Trata-se de um tema que sinaliza a ruptura da dicotomia entre o público e o privado e apresenta como problema a compatibilidade entre a proteção contra discriminação e a autonomia privada, ${ }^{31}$ pois importam os limites traçados para esta última, em face dos direitos fundamentais. Considerando-se que discriminar é "tratar distintamente", indaga-se acerca de diversas concepções de discriminação. Há aquelas que são ilícitas ou proibidas, suscitando um juízo negativo. Mas há situações de discriminação que são lícitas ou permitidas, e até mesmo impostas,

\footnotetext{
${ }^{27}$ PERLINGIERI, Pietro. Perfis do Direito Civil. Introdução ao Direito Civil Constitucional. Tradução e Maria Cristina de Cicco. 3. ed., Rio de Janeiro: Renovar, 1997, p. 280.

${ }^{28}$ PRATA, op. cit., p. 77.

${ }^{29}$ LARENZ, Karl. Derecho Justo. Fundamentos de Etica Juridica. Trad.: Luis Díez-Picazo. Madrid: Editorial Civitas, p. 67-68.

${ }^{30}$ MOTA PINTO, Paulo. Autonomia Privada e Discriminação: algumas notas. In: SARLET, Ingo Wolfgang (coord.). Constituição, Direitos Fundamentais e Direito Privado. Porto Alegre: Livraria do Advogado, 2006. p. 361-404, p. 379.

${ }^{31}$ PINTO, op. cit., p. 364.

${ }^{32}$ Klaus Adomeit apud PINTO, op. cit., p. 364.
} 
caracterizando-se como positivas. Cogita-se que grande parte das situações de discriminação no Direito Privado são permitidas. ${ }^{33}$

Tal fato explica-se pela natureza de direito fundamental conferida à autonomia privada, na medida em que expressa uma liberdade de modelação da esfera jurídica e que se traduz no poder de fazer escolhas diferenciadas, segundo o livre arbítrio do sujeito. Para tanto, a ninguém é dado revelar os motivos de suas escolhas, prevalecendo critérios subjetivos, que fazem da possibilidade de discriminar o "reverso da autonomia privada". Semelhante prevalência da liberdade limita a extensão do princípio da igualdade no Direito Privado, de tal modo, a se afirmar que se um tratamento desigual caracterizasse afronta àquele princípio, a autonomia privada seria destruída. ${ }^{34}$

Afastando-se a proteção contra discriminação no Direito Privado, alinham-se como críticas: (i) o temor de aniquilamento da liberdade econômica e da autonomia privada e (ii) a eficiência econômica. A primeira crítica baseia-se no argumento que a proibição de discriminação ao particular ensejaria uma limitação injustificável da autonomia privada. Tal concepção está ancorada em uma rígida separação entre Estado e sociedade, concebendo-se a liberdade contratual como uma faculdade pré-existente ao Estado, que deve ser protegida pelos poderes públicos. ${ }^{35}$ Deste modo, o Direito Privado deveria permanecer inerte frente às discriminações, suscitando a não intervenção estatal. A segunda crítica vale-se do critério da eficiência, tecido pela Análise Econômica do Direito. Os contratos discriminatórios são ineficientes economicamente, ensejando com o passar do tempo, uma redução das situações de discriminação. ${ }^{36}$ Ambos os argumentos convergem para 0 mesmo ponto: elegem a autonomia privada como um dogma, um valor absoluto, cujas limitações são excepcionais. E afastam-se dos fundamentos axiológicos delineados pela tutela constitucional àquele princípio, assentado na dignidade da pessoa humana. Por isso, tais críticas devem ser rejeitadas.

Nesse momento, voltam-se as atenções para verificar como a relação entre autonomia privada e discriminação foi enfrentada pela experiência europeia, traduzida na edição de diretivas que acolhem o direito à igualdade de tratamento, e ingressam nos Direitos internos dos Estados, ensejando a proteção contra discriminação no Direito Privado.

\section{A EXPERIÊNCIA EUROPEIA: O PRINCÍPIO DA NÃO DISCRIMINAÇÃO NO DIREITO PRIVADO}

É possível sustentar, com base no art. $2^{\circ}$ da Declaração Universal dos Direitos Humanos de 1948, que a proibição a certos tipos de discriminação

\footnotetext{
${ }^{33}$ MOTA PINTO, op. cit., p. 367.

${ }^{34}$ MOTA PINTO, op. cit., p. 382-383.

${ }^{35}$ RULL, Ariadna Aguilera. Prohibición de Discriminación y Libertad de Contratación. InDret. Revista para el Análisis del Derecho, Barcelona, p. 2-30, fev. 2009. Disponível em: WWW.INDRET.COM. Acesso em: 05 ago. 2013, p. 17.

${ }^{36}$ SILVA, op. cit., p. 391.
} 
constitui-se em um direito humano ${ }^{37}$. Deste modo, as distinções em razão do sexo ou orientação sexual, da raça ou origem étnica, da idade, da religião ou convicções e de deficiências, despertou a atenção do legislador europeu, que se dedicou à tarefa de elaborar uma legislação antidiscriminatória. Para tanto, a União Europeia vale-se de diretivas, que trazem consigo o princípio da igualdade de tratamento, especialmente no que se refere à discriminação em razão da raça e do sexo. Neste sentido, destaca-se a Diretiva 2000/43/CE de "igualdade racial", que dispõe sobre a aplicação do princípio da igualdade de tratamento entre pessoas sem distinção de raça ou origem étnica. $\mathrm{E}$ a Diretiva 2004/113/CE de "discriminação em razão do gênero", dispondo sobre o princípio da igualdade de tratamento entre homens e mulheres no acesso a bens e serviços e seu fornecimento. ${ }^{38}$

Neste cenário, indaga-se pela existência do princípio da não discriminação no Direito Privado Europeu, no âmbito do contrato. ${ }^{39}$ Parte-se de uma análise da proteção contra discriminação nas diretivas da União Europeia e sua recepção na diversidade de sistemas jurídicos dos países que a integram, contrapondo-se o Direito alemão e espanhol. As Diretivas 2000/43/CE e 2004/113/CE dedicam-se ao conceito de discriminação, desdobrando-o em discriminação direta e indireta, estabelecem o âmbito de aplicação da proibição de discriminação e as sanções que lhe são aplicáveis. ${ }^{40}$

A discriminação direta é referida pelo art. $2^{\circ}$ da Diretiva 2004/113/CE, caracterizando-se como uma situação em que a pessoa, em virtude dos sinais discriminatórios que porta, recebe tratamento menos favorável ao que possa ser dado à pessoa em situação comparável. ${ }^{41}$ Trata de proteger essencialmente o indivíduo, atentando-se contra a sua dignidade como pessoa humana. Deste modo, impõe-se uma vinculação imediata da proibição de discriminação entre particulares e um dever de vigilância às entidades públicas. ${ }^{42}$

Contudo, o foco da discriminação pode se deslocar do individuo para o grupo: é a discriminação indireta. Ela ocorre quando disposições, critérios ou procedimentos, aparentemente neutros, colocam um grupo de pessoas em desvantagem em face de outras. A partir do art. $2^{\circ}$ da Diretiva 2004/113/CE, o Tribunal de Justiça das Comunidades Europeias colocou em discussão os casos que envolviam uma remuneração menor para tempo parcial de trabalho.

\footnotetext{
${ }^{37}$ SILVA, op. cit., p. 390.

${ }^{38}$ NEUNER, Jôrg. O Princípio da Igualdade de Tratamento no Direito Privado Alemão. Revista Trimestral de Direito Civil, Rio de Janeiro, v. 37, p. 193-214, jan./mar. 2009, p. 195.

${ }^{39}$ RUIZ, Francisco Infante. La Protección contra la Discriminación mediante el Derecho Privado. InDret. Revista para el Análisis del Derecho. Barcelona, p. 2-17, abr. 2008. Disponível em: WWW.INDRET.COM. Acesso em: 05 ago. 2013, p. 14.

${ }^{40}$ RULL, Ariadna Aguilera. Discriminación Directa e Indirecta. InDret. Revista para el Análisis del Derecho. Barcelona, p. 2-17, abr. 2008. Disponível em: WWW.INDRET.COM Acesso em: 05 ago. 2013, p. 5.

${ }^{41}$ SILVA, op. cit., p. 401-402.

${ }^{42}$ MOTA PINTO, op. cit., p. 372.
} 
Ao se constatar que a maioria dos trabalhadores em regime parcial de trabalho era de mulheres, caracterizou-se uma discriminação indireta em razão do sexo. ${ }^{43}$ Trata-se de uma modalidade que exige para sua configuração a existência de um elemento positivo, a discriminação fática, e outro negativo, a falta de justificativa para a consideração dos sinais discriminatórios. ${ }^{44}$

A exigência de uma "situação de desvantagem particular", prevista pela Diretiva 97/80/CE é o elemento chave da discriminação indireta. No que se refere à discriminação de gênero ela se materializa quando um percentual maior de mulheres do que de homens é prejudicado por uma medida aparentemente neutra. Tal elemento ainda se conjuga com a finalidade legitima, que uma vez presente, afasta a discriminação. Este último elemento não escapa a uma apreciação que dele se faz à luz da proporcionalidade: os meios escolhidos para alcançar a finalidade legítima devem ser necessários e adequados. ${ }^{45}$ Trata-se, portanto, de um comportamento que se dirige contra um grupo ou coletivo de pessoas, e cuja proibição não visa apenas evitar a exclusão do acesso à prestação, mas proteger a integridade dos membros do grupo.

A proibição de discriminação tem seu âmbito de aplicação definido pelo art. $3^{\circ}$ da Diretiva 2004/113/EC. É irrelevante a natureza pública ou privada do ofertante, basta a disponibilidade ao público de bens e serviços, fora do âmbito da vida privada e familiar. Nestes termos, proibir a entrada de certas pessoas a um lugar aberto ao público, em razão de sua raça ou sexo, caracteriza discriminação. ${ }^{46}$

Os contratos de locação e compra e venda de imóveis estariam, inicialmente, excluídos de qualquer possibilidade de discriminação. A possibilidade de escolher a contraparte na locação ou compra e venda de um imóvel pertence ao livre arbítrio do sujeito, compondo o núcleo da autonomia privada. Deste modo, a igualdade não poderia ser invocada para pleitear indenização a quem vende um imóvel a alguém, pelo mesmo preço que fora oferecido a outrem. ${ }^{47}$ Contudo, a discriminação é passível de ser verificada se o exercício da liberdade contratual impede o acesso a bens essenciais, gerando uma exclusão social.

Em contratos de seguro, a utilização de sinais distintivos como idade, sexo ou etnia pode se mostrar discriminatório. Em tais casos, a recusa de contratar ou a resolução do contrato pode revelar uma discriminação indireta. Eis que em tais casos, a utilização de sinais distintivos não atinge apenas $\mathrm{o}$ indivíduo, mas o coletivo ao qual ele pertence. ${ }^{48} \mathrm{Em}$ tais casos, a conduta

\footnotetext{
${ }^{43}$ RULL, Discriminación..., p. 10.

${ }_{44}^{4}$ RULL, Discriminación..., p. 11.

${ }^{45}$ RULL, Discriminación..., p. 12-15.

${ }^{46}$ RULL, Prohibición..., p. 7-9.

${ }^{47}$ MOTA PINTO, op. cit., p. 383.

${ }^{48}$ RULL, Prohibición..., p. 15.
} 
discriminatória alcança uma transcendência social: marginaliza-se o coletivo, em lugar de promover sua solidariedade. ${ }^{49}$ Deste modo, a

\begin{abstract}
...proibição contra a discriminação pode igualmente ter uma finalidade reportada à sociedade globalmente considerada. A manutenção da paz e da harmonia entre os membros da sociedade - entre os indivíduos e entre os grupos - e a manutenção das condições para uma formação de vontade democrática requer a integração - e não a segregação em 'condomínios' ou ghettos (ainda que em nome, ou como resultado, da defesa de uma opção multiculturalista). ${ }^{50}$
\end{abstract}

As Diretivas 2000/43/CE e 2004/113/CE garantem a igualdade de acesso aos bens e serviços ofertados ao público. Desenha-se uma esfera que conjuga contornos públicos e privados, no qual se vinculam todos os sujeitos a um princípio de não discriminação. Cogita-se no âmbito das sanções suscitadas pelas diretivas, o princípio da igualdade de tratamento, ao qual se vinculam os particulares. ${ }^{51}$ Trata-se de uma eficácia horizontal dos direitos fundamentais, que ultrapassa o desequilíbrio de forças existentes em uma relação contratual. Esta não é condição necessária ou suficiente à discriminação, já que ela supõe a exclusão de uma pessoa ou grupo. Nestes termos, a vulnerabilidade de um contratante pode derivar do fato de pertencer a um grupo, que é objeto de exclusão. ${ }^{52}$ Arremata Ariadna Aguilera Rull que a proibição de discriminação no acesso a bens e serviços imposta pelas Diretivas 2000/43/CE e 2004/113/CE, faz parte de um conceito mais amplo de inclusão do outro, que não se contenta com a dignidade individual. ${ }^{53}$

Em face das diretivas, acima analisadas, Francisco Infante Ruiz indaga acerca da existência de um "princípio de proibição de discriminação no Direito Privado". ${ }^{54}$ Tal princípio, por sua vez, ingressa nos sistemas jurídicos dos países que compõem a União Europeia, que devem se conformar ao Direito Comunitário. Segundo Francisco Infante Ruiz a recepção de tais diretivas pelos países que compõem a União Europeia é um debate que se trava no âmbito de cada país, ${ }^{55}$ o que se caracteriza por uma diversidade de soluções. Em lugar de implementar cada uma das diretivas em seu Direito interno, a Alemanha optou por promulgar uma Lei Geral de Igualdade de Tratamento (AGG) de 14 de agosto de 2006. Já com recentes modificações, tal lei prevê uma ampla proteção contra discriminação no Direito Privado, também se referindo às distinções por motivo de religião, deficiência, idade e identidade sexual. ${ }^{56}$

\footnotetext{
${ }^{49}$ RULL, Prohibición..., p. 8 e 15.

50 MOTA PINTO, op. cit., p. 373.

${ }^{51}$ RULL, Prohibición..., p. 15 e 17.

${ }^{5}$ RULL, Prohibición..., p. 19.

${ }^{53}$ RULL, Prohibición..., p. 26.

${ }^{54}$ RUIZ, La Protección..., p. 9.

${ }^{55}$ RUIZ, La Protección..., p. 8.

${ }^{56}$ NEUNER, op. cit., p. 195.
} 
Diversamente, o Direito espanhol optou por transpor as diretivas para o Direito interno, por meio da aprovação de quatro leis, com âmbito de aplicação distintas, segundo Ariadna Aguilera Rull: ${ }^{57}$ Lei $n^{\circ} 51$ de 2 de dezembro de 2003 , que incorporou as Diretivas 2000/43/CE e 2000/78/CE, que tratam da igualdade de oportunidades, não discriminação e acesso universal às pessoas com deficiência; a Lei $n^{\circ} 53$ de 10 de dezembro de 2003 que trata de medidas fiscais, administrativas e de ordem social; e a Lei orgânica $n^{\circ} 3$ de 22 de março de 2007, sobre igualdade entre homens e mulheres, que abarca todos os setores do ordenamento jurídico. ${ }^{58}$

A partir de um exame comparativo entre a transposição das diretivas nos cenários jurídicos, alemão e espanhol, Ariadna Aguillera Rull aponta que na lei alemã há um único conceito de discriminação, enquanto nas leis espanholas há várias discriminações distintas. O caráter genérico impresso à recepção do princípio da não discriminação no Direito Privado alemão, torna-a mais vantajosa em comparação à recepção do princípio da não discriminação no Direito Privado espanhol:

La ventaja de transposición alemana frente a la española es que a la definición de discriminación es la misma independientemente de la razón que ha motivado la conducta discriminatoria. En el caso español, por el contrario, cada una de las leyes prevé un concepto de discriminación distinto, diferencia que no está justificada y impide que el derecho de antidiscriminación funcione como un sistema cerrado y coherente. ${ }^{59}$

Atenta-se para a AGG como um enunciado do princípio da igualdade de tratamento ensejando a proteção contra discriminação como um princípio legal e de amplitude geral no Direito Privado alemão. Segundo Jörg Neuner o princípio da igualdade, presente no art. $3^{\circ}$ da Lei Fundamental não tem uma eficácia horizontal, ensejando deveres de proteção nas relações interprivadas. A igualdade de tratamento não se caracteriza como uma restrição à autonomia privada, mas um direito social que exige uma intervenção nos direitos de liberdade em casos excepcionais. ${ }^{60}$

Em conformidade com a intensidade desta intervenção, identificam-se: (i) mandamentos gerais de atuação; (ii) mandados de igualdade de tratamento; (iii) proibições de diferenciação. Os mandamentos gerais de atuação constituem-se em deveres erga omnes, que impõem ao destinatário a obrigação de contratar

\footnotetext{
${ }^{57}$ RULL, Discriminación..., p. 5.

${ }^{58}$ RUIZ, La Protección..., p. 9. De modo semelhante, o direito português aprovou a Lei $n^{\circ} 14$ de 12 de março de 2008, que "Proíbe e sanciona a discriminação em função do sexo no acesso a bens e serviços de fornecimento", transpondo para a ordem jurídica interna a Diretiva 20048/113/CE (LOUREIRO, Carlos Gabriel da Silva. Liberdade Contratual e Discriminação em Função do Sexo: a Lei $n^{\circ}$ 14/2008. Revista de Estudos Politécnicos, Barcelos, v. VIII, no 13, p. 241-255, 2010, Disponível em: http://www.scielo.gpeari.mctes.pt/scielo.php?script=sci_serial\&pid=1645-9911\&lng=en. Acesso em: 05 ago. 2013, p. 241).

${ }^{59}$ RULL, Discriminación..., p. 2.

${ }^{60}$ NEUNER, op. cit., p. 202.
} 
com qualquer pessoa. Tal obrigação impõe-se aos provedores de bens coletivos, como a energia elétrica, ou ainda, de bens necessários a promover o mínimo existencial. Em tais casos, o mandamento de igualdade atua em conformidade com uma justiça distributiva no Direito Privado. ${ }^{61}$

Em face dos mandamentos de igualdade de tratamento exige-se que pessoas que compõem um grupo sejam tratadas do mesmo modo. Para tanto, protege-se os membros de uma família, exigindo que sejam tratados igualmente, como no direito do cônjuge ou companheiro ingressar na posição de locatário. A igualdade de tratamento também deve ser observada na inexecução das obrigações: o devedor que pretende uma liberação parcial de suas obrigações deve oferecer a prestação aos seus credores em igualdade condições. ${ }^{62}$

Exige-se que as decisões tomadas com base na autonomia privada não dependam de determinados critérios, sob pena de se constituírem em discriminação. São as proibições de diferenciação, que protegem contra a exclusão social. Deste modo, uma pessoa não pode ser desfavorecida em razão do sexo ou origem étnica. Quanto mais amplo for o catálogo de sinais protegidos, mais igualdade se alcançará. ${ }^{63}$

Considerando a intervenção do legislador, recolhe-se da experiência europeia, um princípio geral de não discriminação no Direito Privado, seja no Direito Comunitário ou nos Direitos internos dos países que compõem a União Europeia. Indaga-se, à semelhança destes países, acerca da existência de um princípio geral de não discriminação no Direito Privado brasileiro.

\section{O DIREITO FUNDAMENTAL À IGUALDADE DE TRATAMENTO E A PROTEÇÃO CONTRA DISCRIMINAÇÃO NO CONTRATO NO DIREITO BRASILEIRO}

Ao se contrapor o Direito brasileiro à experiência europeia, não se acha a proteção contra discriminação no Direito Privado na legislação ordinária ou em disposições semelhantes às das diretivas europeias. A proteção decorre diretamente da Constituição, o que segundo Jorge Cesa Ferreira da Silva, "acentua o papel do processo hermenêutico" ${ }^{64}$ Paradoxalmente, está ausente um debate aprofundado sobre o tema, tanto por parte da doutrina como da jurisprudência. Não obstante ofereça instrumentos para uma ampla proteção contra discriminação, o Direito brasileiro pouco se pronuncia sobre o assunto, atendo-se, eventualmente, aos casos de discriminação individual, e não atentando para os casos de discriminação indireta, afirmando Jorge Cesa Ferreira da Silva:

...casos relativos à chamada 'discriminação direta escondida' permanecem sem sanção, sobretudo em razão das dificuldades de prova e da inexistência de regra específica sobre inversão do respectivo ônus.

\footnotetext{
${ }^{61}$ NEUNER, op. cit., p. 207.

62 NEUNER, op. cit., p. 208-209.

${ }^{63}$ NEUNER, op. cit., p. 210.

${ }^{64}$ SILVA, op. cit., p. 392 e 397.
} 
Uma intervenção do legislador, portanto, mostra-se aconselhável, sobretudo para estabelecer o âmbito e os instrumentos da proteção de grupos, assim como as conseqüências jurídicas decorrentes de atos discriminatórios. ${ }^{65}$

Ao se indagar sobre a existência de um princípio geral de não discriminação no Direito Privado brasileiro, à semelhança da União Europeia, a resposta tenderia a ser negativa. Com vistas a contrariar semelhante afirmação, desfazem-se as barreiras entre o público e o privado, para assentar na eficácia dos direitos fundamentais nas relações interprivadas a proteção contra discriminação no contrato. Desenham-se os contornos de um direito fundamental à igualdade de tratamento, sinalizando a existência de um princípio implícito de proibição de discriminação no cenário jurídico nacional.

Expressamente consignado no caput do art. $5^{\circ}$ da Constituição da República, o princípio da igualdade é uma norma que enseja o direito fundamental à igualdade de tratamento. ${ }^{66} \mathrm{O}$ sentido contido na expressão "todos são iguais perante a lei" deve ultrapassar, contudo, a concepção de uma igualdade formal, para delinear uma igualdade substancial, historicamente situada. Em sua dimensão positiva, ela se traduz no mandamento de tratar as pessoas desiguais em conformidade com sua desigualdade. Considerando-se o princípio da igualdade como um substrato da dignidade da pessoa humana, ${ }^{67}$ não basta que todos os cidadãos sejam dotados dos mesmos direitos, mas que reclamem para si o reconhecimento de sua diversidade em relação ao outro. ${ }^{68}$

Proclama-se o direito à diferença, que em lugar de reivindicar uma "identidade humana comum" exige o reconhecimento das diferenças. Reconhecendo-se que a humanidade é diversificada e multicultural, deposita-se no reconhecimento do outro o mandamento de igualdade. ${ }^{69}$ Deste modo, o reverso da igualdade é a proibição de discriminação. Trata-se de uma dimensão negativa, que conjugada à dimensão positiva, sintetiza o princípio da igualdade no imperativo cultural, afirmado por Boaventura de Sousa Santos: "temos o direito a ser iguais quando a diferença nos inferioriza; temos o direito a ser diferentes quando a igualdade nos descaracteriza". ${ }^{70}$

A proibição de discriminação contida na dimensão negativa do direito fundamental à igualdade de tratamento decorre da cláusula geral do caput do art. $5^{\circ}$, combinado com o art. $3^{\circ}, \mathrm{IV}^{71}$ ao estabelecer dentre os objetivos da

\footnotetext{
${ }^{65}$ SILVA, op. cit., p. 403.

66 STEINMETZ, Wilson. A Vinculação dos Particulares a Direitos Fundamentais. São Paulo: Malheiros, 2004, p. 231-232.

${ }^{67}$ MORAES, Maria Celina Bodin de. Danos à Pessoa Humana: uma leitura civil-constitucional dos danos morais. Rio de Janeiro: Renovar, 2003, p. 85.

${ }^{68}$ Denninger apud Moraes, 2003, p. 87.

${ }^{69}$ MORAES, op. cit., p. 88.

${ }^{70}$ SANTOS, Boaventura de Sousa. Por uma Concepção Multicultural de Direitos Humanos. In: BALDI, César Augusto. Direitos Humanos na Sociedade Cosmopolita. Rio de Janeiro: Renovar, 2004, p. 239-277, p. 272.

${ }^{71}$ STEINMETZ, op. cit., p. 234.
} 
República "promover o bem de todos, sem preconceitos de origem, raça, sexo, cor, idade e quaisquer outras formas de discriminação". A localização da proteção contra discriminação dentre os objetivos da República, contidos neste artigo, torna a extinção de discriminações uma tarefa do Estado, e "não se restringindo a uma mera dedução do princípio da igualdade ou dos direitos fundamentais", segundo Jorge Cesa Ferreira da Silva. ${ }^{2}$ Trata-se do reflexo de uma "Constituição Dirigente", acepção atribuída a Canotilho, que para além da declaração e garantia de direitos, impõe ao Estado a tarefa de alcançar uma sociedade mais igualitária. Para tanto, atribui-se ao Judiciário um papel de destaque para o alcance de semelhante tarefa. ${ }^{73}$

As bases constitucionais de 1988 ainda rendem à proibição de discriminação, um catálogo aberto de sinais protegidos, ao se referir a "quaisquer outras formas de discriminação". Para tanto, também se consideram os sinais do art. $7^{\circ}$, como sexo, idade, cor, estado civil (XXV), saúde (XXXI) e trabalho (XXXII), no art. 227, § $6^{\circ}$, a filiação, e "qualquer discriminação atentatória dos direitos e liberdades fundamentais" no art. $5^{\circ}, \mathrm{XLI}$, da Constituição da República. ${ }^{74}$

Em conformidade com 0 art. $5^{\circ}, \S 1^{\circ}$, da Constituição da República, é possível afirmar que a proibição de discriminação é uma norma de eficácia imediata, impondo sua observância pelos entes públicos. Resta saber, se semelhante eficácia também vincula os particulares. Na tentativa de esboçar uma resposta, pode-se invocar o magistério de Paulo Mota Pinto, para quem os casos de discriminação não podem ser resolvidos tão somente à luz de princípios constitucionais como o da igualdade. ${ }^{75}$ Assevera que o combate à discriminação enseja uma vinculação dos poderes do Estado, delineando uma interpretação do Direito Privado conforme os direitos fundamentais. ${ }^{76}$ Tais argumentos ensejam o debate acerca da eficácia dos direitos fundamentais nas relações interprivadas, uma vez que delineiam a colisão entre o princípio da igualdade e a autonomia privada. No Direito brasileiro a maioria da doutrina e da jurisprudência inclina-se em favor da teoria da eficácia imediata dos direitos fundamentais nas relações interprivadas. É o que se recolhe dos ensinamentos de Ingo Wolfgang Sarlet, ao sustentar uma vinculação prima facie dos particulares àqueles direitos. Contudo, não há uniformidade na aplicação desses direitos nas relações entre particulares, o que exige decisões diferenciadas, pautadas na ponderação dos valores que estão presentes no caso concreto. ${ }^{77}$

No que se refere ao direito fundamental à igualdade de tratamento, Wilson Steinmetz sintetiza a discussão no Direito brasileiro. Cogitando de sua dimensão negativa, a norma de proibição de discriminação tem eficácia

\footnotetext{
${ }^{72}$ SILVA, op. cit., p. 406.

73 SILVA, op. cit., p. 405.

74 STEINMETZ, op. cit., p. 235.

${ }^{75}$ MOTA PINTO, op. cit., p. 367.

${ }^{76}$ MOTA PINTO, op. cit., p. 368.

${ }^{77}$ SARLET, Ingo Wolfgang. A Eficácia dos Direitos Fundamentais. 5. ed., Porto Alegre: Livraria do Advogado, 2005, p. 382-383.
} 
imediata nas relações entre particulares. Argumenta que invocar o art. $5^{\circ}, \mathrm{XLI}$, da Constituição da República, para afastar a eficácia imediata da norma que proíbe discriminação, seria correto no âmbito do direito penal, em face do princípio da legalidade, mas não no Direito Privado, cabendo ao julgador "ex constitutione, anular, impedir, fazer cessar ou reparar atos ou condutas discriminatórias violadoras do princípio da igualdade".

Já no que se refere à dimensão positiva, que enseja o mandamento de tratamento de igualdade, sustenta-se que obrigar os particulares, no exercício da autonomia privada, a apresentar critérios objetivos que justifiquem suas escolhas eliminaria a própria liberdade no Direito Privado. Contudo, a eficácia do princípio da igualdade seria justificável quando o particular detém uma posição de monopólio ou oligopólio, ou um forte poder social, e quando estão em jogo bens e serviços essenciais e de interesse público, ou quando há oferta ao público em geral, e, ainda, quando os particulares estão na posição de concessionários ou permissionários de serviço público. ${ }^{79}$

Diante da incursão realizada no Direito brasileiro, é possível afirmar a existência de um princípio implícito de proibição de discriminação no Direito Privado, mas que se distancia da experiência europeia, em face das seguintes especificidades: (i) enquanto a Constituição brasileira apresenta um catálogo aberto de sinais protegidos, a lei alemã encerra a discriminação nas relações interprivadas em um catálogo fechado, com vistas a conter a incerteza que tal abertura poderia gerar; (ii) enquanto a lei espanhola distingue a discriminação direta da indireta, e submete esta última a uma detalhada disciplina jurídica, o Direito brasileiro atenta para os casos de discriminação individual, não alcançando a discriminação indireta, revelando-se, neste aspecto, menos democrático que o Direito europeu; (iii) o papel amplo conferido aos tribunais pelo constituinte de 1988, possibilita a eficácia imediata do direito fundamental à igualdade de tratamento, quando em colisão com a autonomia privada, sem desconsiderar a necessidade de ponderar seu alcance em cada caso concreto. Já a lei alemã estabelece mandados de atuação, de igualdade de tratamento e de proibições de diferenciação, atentando para o imperativo de tutela do Estado frente aos particulares. Eis que a Lei Fundamental revela-se, na acepção de Jorge Cesa Ferreira da Silva, como uma "constituição-quadro" que estabelece os limites dentro dos quais devem atuar o legislador e o julgador, enquanto a Constituição brasileira revela-se como uma "Constituição Dirigente", que atribui tarefas ao Estado em face da sociedade. ${ }^{80}$

Cabe, por ora, voltar as atenções à jurisprudência brasileira, indagando sobre o acolhimento da proteção contra discriminação nos contratos, e definindo os contornos da liberdade contratual e da autonomia privada em face do direito fundamental à igualdade de tratamento.

\footnotetext{
${ }^{78}$ STEINMETZ, op. cit., p. 262.

79 STEINMETZ, op. cit., p. 260-263.

80 SILVA, op. cit., p. 404.
} 


\section{CONTORNOS DA LIBERDADE CONTRATUAL EM FACE DA PROIBIÇÃO DE DISCRIMINAÇÃO NA JURISPRUDÊNCIA BRASILEIRA}

O Estado Democrático de Direito faz da defesa do consumidor um direito fundamental, previsto pelo art. $5^{\circ}, X X X I I$, da Constituição da República, que se impõe não apenas ao Estado, mas aos particulares. É a tradução de um personalismo ético, o qual preside a leitura das relações de consumo, ao proteger para além do consumidor, a pessoa humana ${ }^{81}$ fazendo do contrato um "ponto de encontro de direitos fundamentais". ${ }^{2}$ Nesta perspectiva, o direito fundamental à igualdade de tratamento pode vincular os particulares em um contrato, de tal modo, a efetivar a proteção contra discriminação. Indaga-se o modo como as proibições de discriminação incidem no Direito Privado. Segundo Claus-Wilhelm Canaris, a "eficácia imediata assume seu papel quando uma proibição de discriminação serve à proteção da dignidade humana, pois esta, em virtude de sua supremacia absoluta, opera sempre de modo direto." Já nos "casos de proibições de discriminação que tenham por objeto a consecução de fins de natureza profissional, social ou política, a prerrogativa da formatação encontra-se nas mãos do Poder Legislativo". ${ }^{3}$ Com vistas a delinear estas duas possibilidades, empreende-se uma incursão pelo direito contratual brasileiro.

Ao precisar o sentido da função social do contrato, com amparo na interpretação de Judith Martins-Costa, entendendo-se que a liberdade contratual acha-se ligada à autonomia privada como expressão de uma "autonomia privada solidária". Imprime-se à liberdade de contratar um aspecto instrumental, que concretiza os princípios do art. $1^{\circ}$, as "normas objetivo" do art. $3^{\circ}$ e art. 170 , os direitos e garantias do art. $5^{\circ}$ e $7^{\circ}$, da Constituição da República. ${ }^{84}$ Deste modo, a função social não é mero limite externo, mas um "elemento integrativo do campo de função da autonomia privada no domínio da liberdade contratual". ${ }^{85}$ Considerando-se que o art. $3^{\circ}$, IV, da Constituição da República, traz consigo a proibição de discriminação, é possível afirmar que exercer a liberdade de contratar ou a liberdade contratual, violando o direito fundamental à igualdade de tratamento, expresso naquele mandamento constitucional, é atentar contra a função social do contrato.

Corrobora este entendimento, a acepção de função social do contrato teorizada por Gustavo Tepedino. Afasta-se de uma interpretação restritiva,

\footnotetext{
${ }^{81}$ TEPEDINO, Gustavo. As Relações de Consumo e a Nova Teoria Contratual. In: Temas de Direito Civil. Rio de Janeiro: Renovar, 1999. p. 199-215, p. 211.

${ }^{82}$ MARQUES, Cláudia Lima. Contratos no Código de Defesa do Consumidor. 4. ed., v. 1, São Paulo: RT, 2002. p. 256.

${ }_{83}$ Considerações a Respeito da Posição de Proibições de Discriminação no Sistema de Direito Privado. Revista Direitos Fundamentais \& Justiça. Porto Alegre: HS Editora, ano 7, $\mathrm{n}^{\circ}$ 22, p. 15-20, jan./mar. 2013, p. 20.

${ }^{84}$ Reflexões sobre o Princípio da Função Social dos Contratos. Revista GVLaw. São Paulo, v. 1, $\mathrm{n}^{\circ}$ 1, p 41-66, maio 2005, p. 45-47.

${ }^{85}$ MARTINS-COSTA, op. cit., p. 50.
} 
asseverada por parcela da doutrina nacional, segundo a qual a função social do contrato realiza-se por figuras jurídicas já positivadas no ordenamento jurídico, como a lesão ou a resolução por onerosidade excessiva. Por outro lado, não se restringe à mera tutela externa do crédito, que, embora confira caráter autônomo à função social do contrato, rompendo com o princípio da relatividade dos efeitos do contrato para alcançar terceiros, realiza, em última instância, os interesses das partes. Guiado pelo texto constitucional, nos princípios da dignidade da pessoa humana (art. $1^{\circ}$, II), livre iniciativa (art. $1^{\circ}$, IV) e igualdade substancial (art. $3^{\circ}$ ), Gustavo Tepedino define a função social do contrato como a realização de "interesses extracontratuais socialmente relevantes" como a livre concorrência, a defesa do consumidor, a defesa do meio ambiente, a redução das desigualdades regionais e sociais e a busca do pleno emprego. $^{86}$

Tal concepção de função social do contrato figurou na jurisprudência brasileira, por ocasião do julgamento da cobrança de assinatura básica residencial em telefonia fixa, pelo Superior Tribunal de Justiça. ${ }^{87}$ Em seu voto vencido, o Min. Herman Benjamin afirma que a cobrança da assinatura básica em contratos de telefonia fixa deve considerar: (i) a função social da propriedade, da empresa e do contrato; (ii) a defesa do consumidor; (iii) a manutenção do equilíbrio econômico-financeiro; (iv) a redução das desigualdades sociais; (v) a modicidade das tarifas e preços; e (vi) a vedação de discriminação. Em seu voto, o ministro afirma que o contrato de telefonia exige o cumprimento de sua função social e a cobrança da assinatura básica importa em discriminação vedada pelo art. $3^{\circ}$, III, da Lei Geral de Telecomunicações (Lei nº 9.472/97):

A assinatura básica é uma forma de discriminação ao contrário, ao cobrar de ricos e pobres o mesmo valor e a mesma quantidade de pulsos/minutos, como se fossem iguais. Nisso, duplamente viola o art. $3^{\circ}$, da LGT: inviabiliza o acesso de largas parcelas da população aos serviços de telefonia fixa residencial (inciso I) e discrimina "quanto às condições de acesso e fruição do serviço" (inciso II). Numa palavra, é o cavalo-de-tróia da exclusão digital. ${ }^{88}$

Diante das considerações do ministro torna-se possível afirmar que o interesse social a ser alcançado pela função social do contrato de telefonia fixa é dar acesso amplo à população a este serviço. Abrem-se as portas do Direito Privado para que se proíba a discriminação no contrato, sob pena de atentar contra direitos fundamentais.

\footnotetext{
${ }^{86}$ MODENESI, Pedro. Função Social dos Contratos: questões polêmicas na doutrina e na jurisprudência. Revista Trimestral de Direito Civil, Rio de Janeiro, v. 39, p. 185-208, p. 197.

${ }^{87}$ MODENESI, op. cit., p. 201.

${ }^{88}$ BRASIL, Superior Tribunal de Justiça. Recurso Especial no 911.802, Relator: Min. José Delgado, j. 24.10.2007. Disponível em: www.stj.gov.br. Acesso em: 17 ago. 2013.
} 
No âmbito infraconstitucional, é possível encontrar normas de proteção contra discriminação no contrato, como (i) o dever de contratar, (ii) a indenização por danos extrapatrimoniais, (iii) deveres de omissão, (iv) a invalidade de cláusulas contratuais e (v) o inadimplemento das obrigações.

A proteção contra discriminação pode ensejar o dever de contratar, se o exercício negativo da liberdade de celebração do contrato caracterizar uma conduta discriminatória. No âmbito do Código Civil não há tal dever, ensejando o direito à indenização por perdas e danos em caso de recusa discriminatória, constituindo-se em abuso do direito. Já no Código de Defesa do Consumidor, o princípio da vinculatividade da oferta enseja o dever de contratar, admitindo execução específica, em face do art. $35 .{ }^{89}$ Trata-se de uma proteção contra a recusa discriminatória de contratar, uma vez que os contratos de consumo são celebrados independentemente das qualidades pessoais do consumidor. ${ }^{90}$

A atuação discriminatória também pode ensejar o dever de indenizar, quer por violação aos direitos da personalidade ou do interesse na prestação, abrangendo danos patrimoniais e extrapatrimoniais. ${ }^{91} \mathrm{~A}$ indenização por dano moral, prevista no art. $5^{\circ}$, V e X, da Constituição da República, ${ }^{92}$ e no art. 186 do Código Civil, ${ }^{93}$ impõe-se aos casos de lesão aos direitos da personalidade do discriminado. Valendo-se do substrato da dignidade da pessoa humana, Maria Celina Bodin de Moraes sustenta que proceder a diferenciações, sem fundamentação jurídica, é uma forma de violação do direito à igualdade, ensejando dano moral. ${ }^{94}$

Quando a conduta discriminatória importar em lesão aos direitos da personalidade, é possível a imposição de deveres de omissão: o lesado pode exigir a proibição do ato ou ameaça ao seu direito. É a tutela inibitória, prevista nos artigos 12 e 21 do Código Civil. ${ }^{95}$ No âmbito das relações de consumo, o Código de Defesa do Consumidor, no art. $37, \S 2^{\circ}{ }^{96}$ proíbe a

\footnotetext{
89 "Se o fornecedor de produtos e serviços recusar cumprimento à oferta, apresentação ou publicidade, o consumidor poderá, alternativamente e à sua livre escolha: I - exigir o cumprimento forçado da obrigação, nos termos da oferta, apresentação ou publicidade."

${ }^{90}$ SILVA, op. cit., p. 413-414.

${ }_{91}^{91}$ MOTA PINTO, op. cit., p. 402.

92 "Art. $5^{\circ}(\ldots)$

V- é assegurado o direito de resposta, proporcional ao agravo, além da indenização por dano material, moral ou à imagem.

X-são invioláveis a intimidade, a vida privada, a honra e a imagem das pessoas, assegurado o direito a indenização pelo dano material ou moral decorrente de sua violação."

93 "Aquele que, por ação ou omissão voluntária, negligência ou imprudência, violar direito e causar dano a outrem, ainda que exclusivamente moral, comete ato ilícito".

${ }_{94}^{94}$ MORAES, op. cit., p. 90.

95 "Art. 12. Pode-se exigir que cesse a ameaça, ou a lesão, a direito da personalidade, e reclamar perdas e danos, sem prejuízo de outras sanções previstas em lei."

"Art. 21. A vida privada da pessoa natural é inviolável, e o juiz, a requerimento do interessado, adotará as providências necessárias para impedir ou fazer cessar ato contrário a esta norma."

96 "É proibida toda publicidade enganosa ou abusiva. (...) § $2^{\circ}$ É abusiva, dentre outras, a publicidade discriminatória de qualquer natureza, a que incite à violência, explore o medo ou a superstição, se
} 
publicidade "discriminatória de qualquer natureza". Trata-se de publicidade abusiva, cujas sanções acarretam o dever de indenizar e a imposição de abstenção do ato.

Os negócios jurídicos com conteúdo discriminatório podem ser declarados nulos, por atentar contra a lei ou à ordem pública. O Código Defesa do Consumidor traz no art. 51, IV, uma norma aberta que permite caracterizar como abusiva a cláusula contratual que enseja discriminação. Contudo, uma aplicação direta dos direitos fundamentais às relações interprivadas é capaz de traçar as fronteiras do lícito e do ilícito, ensejando a nulidade de cláusulas contratuais. ${ }^{97}$ Já a denúncia discriminatória de um contrato cativo e de longa duração pode caracterizar o inadimplemento das obrigações contratuais. Segundo Jorge Cesa Ferreira da Silva, há uma violação positiva do contrato, impondo-se a indenização por perdas e danos. ${ }^{98}$

A existência de cláusulas gerais no Código Civil e no Código de Defesa do Consumidor, embora reduzam, não afastam a incidência direta do direito fundamental à igualdade de tratamento nas relações contratuais. Antes, possibilitam que os instrumentos de Direito Privado, acima descritos, definam o alcance dos direitos fundamentais no princípio da autonomia privada, em face de cada caso concreto. ${ }^{99}$

A jurisprudência brasileira volta-se para os contratos de consumo, depositando nos planos de saúde a proteção contra discriminação. Em tais contratos, o Superior Tribunal de Justiça firmou o entendimento no sentido de afastar a discriminação por idade. Trata-se de contratos cativos de longa duração, nos quais os usuários que completam sessenta anos ou mais, são surpreendidos pelo aumento dos valores cobrados em razão da mudança de faixa etária. O fundamento comum em todas essas decisões é o art. 15, § $3^{\circ}$, da Lei 10.741/2003, que dispõe:

É facultada a variação das contraprestações pecuniárias estabelecidas nos contratos de planos e seguro de saúde de que trata esta lei em razão da idade do consumidor, desde que sejam previstas no contrato inicial as faixas etárias e os percentuais de reajustes incidentes em cada uma delas, conforme critérios e parâmetros gerais fixados pelo CNSP.

(...) $\S 3^{\circ}$. É vedada a discriminação do idoso nos planos de saúde pela cobrança de valores diferenciados em razão da idade.

Amparado em semelhante fundamento, o Superior Tribunal de Justiça acolheu a demanda de usuário idoso de plano de saúde, que após completar

\footnotetext{
aproveite da deficiência de julgamento e experiência da criança, desrespeite valores ambientais, ou que seja capaz de induzir o consumidor a se comportar de forma prejudicial ou perigosa à sua saúde ou segurança."

${ }^{97}$ SILVA, op. cit., p. 408.

${ }^{98}$ SILVA, op. cit., p. 415.

${ }^{99}$ SILVA, op. cit., p. 410.
} 
sessenta anos, teve a mensalidade reajustada em 185\% em decorrência da mudança da faixa etária:

Direito civil e processual civil. Recurso especial. Ação revisional de contrato de plano de saúde. Reajuste em decorrência de mudança de faixa etária. Estatuto do idoso. Vedada a discriminação em razão da idade.

- O Estatuto do idoso veda a discriminação da pessoa idosa com a cobrança de valores diferenciados em razão da idade (art. 15, § $3^{\circ}$ ).

- Se o implemento da idade, que confere à pessoa a condição jurídica de idosa, realizou-se sob a égide do Estatuto do Idoso, não estará o consumidor usuário do plano de saúde sujeito ao reajuste estipulado no contrato, por mudança de faixa etária.

- A pretensão de reajuste contida na cláusula depende de um elemento básico prescrito na lei e o contrato só poderá operar seus efeitos no tocante à majoração das mensalidades do plano de saúde, quando satisfeita a condição contratual e legal, qual seja, o implemento da idade de 60 anos.

- Enquanto o contratante não atinge o patamar etário preestabelecido, os efeitos da cláusula permanecem condicionados a evento futuro e incerto, não se caracterizando o ato jurídico perfeito, tampouco se configurando o direito adquirido da empresa seguradora, qual seja, de receber os valores de acordo com o reajuste predefinido.

- Apenas como reforço argumentativo, porquanto não prequestionada a matéria jurídica, ressalte-se que 0 art. 15 da Lei $n^{\circ}$ 9.656/98 faculta a variação das contraprestações pecuniárias estabelecidas nos contratos de planos de saúde em razão da idade do consumidor, desde que estejam previstas no contrato inicial as faixas etárias e os percentuais de reajuste incidentes em cada uma delas, conforme normas expedidas pela ANS. No entanto, o próprio parágrafo único do aludido dispositivo legal veda tal variação para consumidores com idade superior a 60 anos.

- E mesmo para os contratos celebrados anteriormente à vigência da Lei $n^{\circ}$ 9.656/98, qualquer variação na contraprestação pecuniária para consumidores com mais de 60 anos de idade está sujeita à autorização prévia da ANS (art. 35-E da Lei no 9.656/98).

- Sob tal encadeamento lógico, o consumidor que atingiu a idade de 60 anos, quer seja antes da vigência do Estatuto do Idoso, quer seja a partir de sua vigência ( $1^{\circ}$ de janeiro de 2004), está sempre amparado contra a abusividade de reajuste das mensalidades com base exclusivamente no alçar da idade de 60 anos, pela própria proteção oferecida pela Lei dos Planos de Saúde e, ainda, por efeito reflexo da Constituição Federal que estabelece norma de defesa do idoso no art. 230.

- A abusividade na variação das contraprestações pecuniárias deverá ser aferida em cada caso concreto, diante dos elementos que o Tribunal de origem dispuser.

- Por fim, destaque-se que não se está aqui alçando o idoso a condição que o coloque à margem do sistema privado de planos de assistência à saúde, porquanto estará ele sujeito a todo o regramento emanado em lei 
e decorrente das estipulações em contratos que entabular, ressalvada a constatação de abusividade que, como em qualquer contrato de consumo que busca primordialmente o equilíbrio entre as partes, restará afastada por norma de ordem pública.

Recurso especial não conhecido. ${ }^{100}$

O voto da Ministra Nancy Andrighi considerou a incidência imediata do Estatuto do Idoso aos contratos celebrados antes da referida lei. Eis que a cláusula que prevê a mudança da faixa etária tem natureza aleatória e como a Lei 10.741/2003 traz consigo a cogência de suas normas e a natureza de ordem pública, estas têm incidência imediata sobre o contrato. Para tanto, o tribunal utilizou-se de instrumentos típicos de Direito Privado, como a revisão das prestações do contrato, tornando efetivo o mandamento infraconstitucional do art. 15, $\S 3^{\circ}$ do Estatuto do Idoso.

De modo semelhante, o Superior Tribunal de Justiça considerou abusiva cláusula contratual, declarando sua nulidade, por estabelecer um aumento de $100 \%$ e $200 \%$ para faixas etárias de sessenta e setenta anos, respectivamente, na mensalidade de plano de saúde de pessoa idosa:

Direito civil e processual civil. Estatuto do idoso. Planos de saúde. Reajuste de mensalidades em razão de mudança de faixa etária. Vedação.

- O plano de assistência à saúde é contrato de trato sucessivo, por prazo indeterminado, a envolver transferência onerosa de riscos, que possam afetar futuramente a saúde do consumidor e seus dependentes, mediante a prestação de serviços de assistência médico-ambulatorial e hospitalar, diretamente ou por meio de rede credenciada, ou ainda pelo simples reembolso das despesas.

- Como característica principal, sobressai o fato de envolver execução periódica ou continuada, por se tratar de contrato de fazer de longa duração, que se prolonga no tempo; os direitos e obrigações dele decorrentes são exercidos por tempo indeterminado e sucessivamente.

- Ao firmar contrato de plano de saúde, o consumidor tem como objetivo primordial a garantia de que, no futuro, quando ele e sua família necessitarem, obterá a cobertura nos termos em que foi contratada.

- O interesse social que subjaz do Estatuto do Idoso, exige sua incidência aos contratos de trato sucessivo, assim considerados os planos de saúde, ainda que firmados anteriormente à vigência do Estatuto Protetivo.

- Deve ser declarada a abusividade e consequente nulidade de cláusula contratual que prevê reajuste de mensalidade de plano de saúde calcada exclusivamente na mudança de faixa etária - de 60 a 70 anos respectivamente, no percentual de $100 \%$ e $200 \%$, ambas inseridas no âmbito de proteção do Estatuto do Idoso.

${ }^{100}$ BRASIL, Superior Tribunal de Justiça. Recurso Especial $n^{\circ}$ 809.329, Relator: Min. Nancy Andrighi, j. 25.03.2008. Disponível em: www.stj.gov.br. Acesso em: 17 ago. 2013. 
- Veda-se a discriminação do idoso em razão da idade, nos termos do art. 15, $\S 3^{\circ}$, do Estatuto do Idoso, o que impede especificamente 0 reajuste das mensalidades dos planos de saúde que se derem por mudança de faixa etária: tal vedação não envolve, portanto, os demais reajustes permitidos em lei, os quais ficam garantidos às empresas portadoras de planos de saúde, sempre ressalvada a abusividade.

Recurso especial conhecido e provido. ${ }^{101}$

À luz do art. 15, $\S 3^{\circ}$ do Estatuto do Idoso, a cláusula contratual foi declarada abusiva, com base na cláusula geral do art. 51, IV, da Lei 8.078/90 ao dispor que são abusivas as cláusulas que "estabeleçam obrigações consideradas iníquas, abusivas, que coloquem o consumidor em desvantagem exagerada, ou sejam incompatíveis com a boa-fé ou a equidade".

Em caso semelhante, o Superior Tribunal de Justiça também vedou a discriminação de idoso em razão da idade, com base no art. $15, \S 3^{\circ}$, do Estatuto do Idoso, afastando a possibilidade de denúncia do contrato por parte da operadora de plano de saúde. Alegou-se, para tanto, a alta sinistralidade causada por elevado número de usuários idosos em plano de saúde coletivo:

Direito do consumidor. Estatuto do Idoso. Planos de saúde. Rescisão de plano de saúde em razão da alta sinistralidade do contrato, caracterizada pela idade avançada dos segurados. Vedação.

1. Nos contratos de seguro em grupo, o estipulante é mandatário dos segurados, sendo parte ilegítima para figurar no polo passivo da ação de cobrança. Precedentes.

2. Veda-se a discriminação do idoso em razão da idade, nos termos do art. 15, § $3^{\circ}$, do Estatuto do Idoso, o que impede especificamente 0 reajuste das mensalidades dos planos de saúde sob alegação de alta sinistralidade do grupo, decorrente da maior concentração dos segurados nas faixas etárias mais avançadas; essa vedação não envolve, todavia, os demais reajustes permitidos em lei, os quais ficam garantidos às empresas prestadoras de planos de saúde, sempre ressalvada a abusividade.

3. Recurso especial conhecido e provido. ${ }^{102}$

Diversamente, em demanda promovida pelo Instituto Brasileiro de Defesa do Consumidor - IDEC, a discriminação de usuário idoso em plano de saúde não foi afastada. Para tanto, justificou-se a discriminação, entendendo válido o reajuste em face da mudança de faixa etária:

Direito civil. Consumidor. Plano de saúde. Ação civil pública. Cláusula de reajuste por mudança de faixa etária. Incremento do risco subjetivo.

101 BRASIL, Superior Tribunal de Justiça. Recurso Especial no 989.380, Relator: Min. Nancy Andrighi, j. 06.11.2008. Disponível em: www.stj.gov.br. Acesso em: 17 ago. 2013.

${ }^{102}$ BRASIL, Superior Tribunal de Justiça. Recurso Especial $n^{\circ} 1.106 .557$, Relator: Min. Nancy Andrighi, j. 16.09.2010. Disponível em: www.stj.gov.br. Acesso em: 17 ago. 2013. 
Segurado idoso. Discriminação. Abuso a ser aferido caso a caso. Condições que devem ser observadas para validade do reajuste.

1. Nos contratos de seguro de saúde, de trato sucessivo, os valores cobrados a título de prêmio ou mensalidade guardam relação de proporcionalidade com o grau de probabilidade de ocorrência do evento risco coberto. Maior o risco, maior o valor do prêmio.

2. É de natural constatação que quanto mais avançada a idade da pessoa, independentemente de estar ou não ela enquadrada legalmente como idosa, maior é a probabilidade de contrair problema que afete sua saúde. Há uma relação direta entre incremento de faixa etária e aumento de risco de a pessoa vir a necessitar de serviços de assistência médica.

3. Atento a tal circunstância, veio o legislador a editar a Lei Federal $n^{\circ} 9.656 / 98$, rompendo o silêncio que até então mantinha acerca do tema, preservando a possibilidade de reajuste da mensalidade de plano ou seguro saúde em razão da mudança de faixa etária do segurado, estabelecendo, contudo, algumas restrições e limites a tais reajustes.

4. Não se deve ignorar que o Estatuto do Idoso, em seu art. $15, \S 3^{\circ}$, veda "a discriminação do idoso nos planos de saúde pela cobrança de valores diferenciados em razão da idade". Entretanto, a incidência de tal preceito não autoriza uma interpretação literal que determine, abstratamente, que se repute abusivo todo e qualquer reajuste baseado em mudança de faixa etária do idoso. Somente o reajuste desarrazoado, injustificado, que, em concreto, vise de forma perceptível a dificultar ou impedir a permanência do segurado idoso no plano de saúde implica na vedada discriminação, violadora da garantia da isonomia.

5. Nesse contexto, deve-se admitir a validade de reajustes em razão da mudança de faixa etária, desde que atendidas certas condições, quais sejam: a) previsão no instrumento negocial; b) respeito aos limites e demais requisitos estabelecidos na Lei Federal n 9.565/98; e c) observância ao princípio da boa-fé objetiva, que veda índices de reajuste desarrazoados ou aleatórios, que onerem em demasia o segurado.

6. Sempre que o consumidor segurado perceber abuso no aumento de mensalidade de seu seguro de saúde, em razão de mudança de faixa etária, poderá questionar a validade de tal medida, cabendo ao Judiciário o exame da exorbitância, caso a caso.

7. Recurso especial provido. ${ }^{103}$

Tais decisões afastam por completo os fundamentos constitucionais, por se ater à proibição de discriminação prevista em sede infraconstitucional. Porém este não foi o caminho escolhido pelo Tribunal de Justiça do Paraná. Em contrato de previdência privada complementar, a aposentadoria em percentuais diferenciados para homens e mulheres foi considerada discriminatória por atentar contra a igualdade de gêneros, prevista no art. 50, I, da Constituição da República, amparando-se no Código de Defesa do Consumidor:

${ }^{103}$ BRASIL, Superior Tribunal de Justiça. Recurso Especial no 866.840, Relator: Min. Raul Araújo, j. 07.07.2011. Disponível em: www.stj.gov.br. Acesso em: 17 ago. 2013. 
Apelação civil - Previdência privada complementar - Suplementação de aposentadoria - Extinção da ação por ilegitimidade ativa de duas autoras - Impossibilidade - Extinção da ação em face da transação e da renúncia havida - Inocorrência - Contrato de adesão - Assinado de forma impositiva - Aplicação do CDC - Requerimento de liltisconsórcio passivo necessário - Despiciência - Alegada prescrição e decadência Regulamento que prevê aponsentadoria com percentual diferenciado entre homens e mulheres - pretensão acolhida no juízo a quo para invalidade de cláusula abusiva - Manutenção da igualdade entre homens e mulheres - Reconhecida a prescrição quinquenal - Insurgência Recurso objetivando manter a aposentadoria em percentual diferenciado entre associados do sexo masculino e feminino - Alegado ato jurídico perfeito que não pode ser invalidado - Ausência de custeio - Outrossim, ofensa à igualdade prevista na Constituição Federal - Infração ao art. 5, I, da CF/88 - Discriminação repelida - Sentença mantida - Recurso desprovido.

1. A renúncia e quitação de direitos e obrigações relativas a planos anteriores significam violar o direito adquirido, já que os direitos decorrentes das normas anteriores integram o patrimônio da parte demandante, de sorte que tal exigência formulada pela entidade previdenciária constitui ofensa ao disposto no inciso XXXVI, do art. $5^{\circ}$ da Constituição Federal.

2. Tratando-se de obrigação de trato sucessivo e caráter alimentar, de natureza previdenciária, a prescrição não atinge o fundo de direito, mas apenas as parcelas anteriores há cinco anos do ajuizamento da ação. Assim, estão prescritos os benefícios não pagos ou pagos de maneira incorreta, anteriores àquele período, conforme decidido na sentença. Súmula 291 do STJ.

3. Embora os postulantes tenham aderido ao novo plano oferecido pela entidade previdenciária, nada impede que possam postular a revisão de cláusulas que entendam abusivas, de acordo como consagrado no artigo $5^{\circ}, \mathrm{XXXV}$, da Constituição Federal.

4. Em sede de aposentadoria proporcional é vedada à Previdência Privada impor cláusulas contratuais que os diferenciem em decorrência do sexo porque homens e mulheres são iguais em direitos e obrigações. ${ }^{104}$

De modo semelhante, o Tribunal de Justiça de São Paulo condenou uma seguradora a indenizar danos morais ao proponente de seguro contra acidentes pessoais, que teve sua proposta recusada, por possuir índice de massa corporal acima da média. Tal recusa de contratar revelou-se discriminatória em relação à pessoa obesa. O tribunal fundamentou sua decisão no princípio da dignidade da pessoa humana, art. $1^{\circ}$, III, e da proibição de discriminação do art. $3^{\circ}$, IV, da Constituição da República:

${ }^{104}$ PARANÁ, Tribunal de Justiça do Paraná. Apelação Cível no 873.083-8, Relator: Des. Luiz Osório Moraes Panza, j. 03.07.2012. Disponível em: www.tjpr.jus.br. Acesso em: 12 ago. 2013. 
Seguro de acidentes pessoais - Ação de indenização por danos morais - Obesidade do proponente - Recusa da proposta pela seguradora Recusa injustificada - Indenização devida - Indenização arbitrada em $\mathrm{R} \$ 10.000,00$. Recurso provido.

(...) o certo é que, com sua conduta, a empresa afrontou a dignidade do autor, dignidade essa que se constitui num dos pilares do Estado Democrático de Direito vigente entre nós, a teor do art. $1^{\circ}$, III, da Constituição Federal. E não se pode olvidar que, consoante a dicção do art. $3^{\circ}$, IV , da mesma Carta Política, também constitui objetivo fundamental da República Federativa do Brasil a promoção do 'bem de todos, sem preconceitos de origem, raça, sexo, cor, idade e quaisquer outras formas de discriminação'.

Tais casos permitem traçar um panorama da jurisprudência brasileira acerca da discriminação nos contratos. Não obstante a existência de um direito fundamental à igualdade de tratamento, ele não encontra alcance no Direito Privado. Os tribunais resolvem os casos de discriminação tão somente com instrumentos típicos de Direito Privado: (i) revisão do contrato; (ii) nulidade de cláusulas abusivas; (iii) limitação ao direito de denúncia do contrato. Para fundamentá-los, as decisões recorrem à proteção contra discriminação contida em disposições expressas de legislação infraconstitucional, como o art. 15, § $3^{\circ}$, do Estatuto do Idoso e art. $3^{\circ}$, III, da LGT. Com tais instrumentos chegam à mesma solução que seria alcançada, se invocada a norma de proibição de discriminação, expressa no art. $3^{\circ}$, IV, da Constituição da República. Isto significa que a proibição de discriminação é um princípio implícito no Direito Privado brasileiro.

Mas, também significa que a jurisprudência brasileira oferece uma proteção mitigada contra discriminação no contrato. Deposita-se na interpretação e aplicação das normas jurídicas o alcance desta proteção: afeto ao positivismo legalista e pouco atento ao "processo hermenêutico" requerido pela aplicação dos direitos fundamentais, o jurista brasileiro não se volta para a tutela constitucional da autonomia privada e para a função social do contrato, que tem contornos constitucionais. Desconsidera a eficácia dos direitos fundamentais no Direito Privado, temendo o aniquilamento da esfera de liberdade que se garante ao contrato. Portanto, pode-se afirmar com Jörg Neuner, que a "autonomia privada não é, todavia, ameaçada apenas por uma intervenção excessiva em direitos de liberdade, mas também por uma insuficiente consideração das condições materiais da liberdade, às quais também pertence, de modo essencial, a proteção diante da discriminação". ${ }^{106}$ Deste modo, a autonomia privada resta incólume em sua acepção clássica e a liberdade contratual não é exercida em conformidade com a função social do contrato.

${ }^{105}$ SÃO PAULO, Tribunal de Justiça de São Paulo, Apelação Cível nº 0026182-80.2011.8.26.0602, Relator: Des. Antonio Nascimento. j. 12.09.2012. Disponível em: www.tjsp.jus.br. Acesso em: 12 ago. 2013.

${ }^{106}$ NEUNER, op. cit., p. 196. 


\section{CONSIDERAÇÕES FINAIS}

O paradoxo identificado no início deste trabalho resta dissipado. Eis que se identificou uma lacuna acerca da proteção contra discriminação no Direito Privado brasileiro. Voltando as atenções para um "novo direito antidiscriminatório" na experiência europeia, foi possível estabelecer um diálogo com o Direito brasileiro, e identificar um princípio implícito de proibição de discriminação nas relações interprivadas.

O caminho percorrido para esta conclusão parte da relação entre autonomia privada e discriminação. De uma "hipertrofia da autonomia da vontade" que permitia ao homem realizar-se como pessoa e afirmar sua liberdade individual, a autonomia privada é redesenhada em face da possibilidade de aplicação direta das normas constitucionais. Invocando-se a tutela constitucional, o princípio passa a encontrar significado em sua funcionalização. Nesta perspectiva, dissipa-se a tensão entre autonomia privada e discriminação, pois o exercício da liberdade contratual pode caracterizar discriminação por atentar contra os direitos fundamentais.

A experiência europeia apoia-se em um conjunto de diretivas, que revelam a existência de um princípio de não discriminação do Direito Privado. Para tanto, distingue-se entre discriminação direta, segundo a qual o indivíduo recebe tratamento menos favorável do que se daria a outra pessoa em situação semelhante, e discriminação indireta, na qual critérios aparentemente neutros colocam um grupo de pessoas em desvantagem em face de outras.

A incorporação das diretivas nos direitos internos dos Estados da União Europeia é um debate travado por cada país. Enquanto o Direito alemão elaborou uma Lei Geral de Igualdade (AGG), ensejando a proteção contra discriminação como um princípio de amplitude geral, o Direito espanhol aprovou diversas leis, que traduzem várias discriminações distintas.

Diversamente da experiência europeia, não há no Direito brasileiro uma proteção expressa contra discriminação no Direito Privado, em sede de legislação ordinária. A proteção decorre diretamente da Constituição da República de 1988, acentuando o papel hermenêutico do intérprete. Trata-se do princípio da igualdade de tratamento, previsto no art. $5^{\circ}$, caput, e art. $3^{\circ}$, IV, estabelecendo a igualdade substancial e o direito à diferença. A proibição de discriminação, encontrada no texto constitucional, tem eficácia imediata nas relações interprivadas. No Direito brasileiro há um catálogo aberto de sinais protegidos, em diversidade ao que se passa no Direito alemão, e trata de casos de discriminação individual, não alcançando a discriminação indireta, ao contrário do que ocorre no Direito espanhol.

No Direito brasileiro, é possível afirmar que a liberdade contratual exercida em violação ao direito à igualdade de tratamento atenta contra a função social do contrato. Contribui para tanto, a concepção de função social do contrato como norma de realização de interesses socialmente relevantes. É possível identificar em normas infraconstitucionais a proteção contra discriminação 
no contrato: a imposição do dever de contratar no Código de Defesa do Consumidor, a compensação por danos morais, a imposição de deveres de omissão, a nulidade de negócios jurídicos e as cláusulas contratuais de limitação ao exercício do direito de denúncia do contrato. Na jurisprudência, o Superior Tribunal de Justiça aplica a proibição de discriminação, presente no Estatuto do Idoso, afastando a discriminação em planos de saúde, que cobram mensalidades mais elevadas em face da mudança de faixa etária. Isso demonstra que, não obstante alguns casos pontuais, a jurisprudência brasileira furta-se à aplicação direita do direito à igualdade de tratamento, previsto constitucionalmente, nas relações interprivadas.

Com efeito, a proteção contra discriminação no contrato no Direito brasileiro é mitigada. Eis que (i) limita-se à aplicação das normas infraconstitucionais que proíbem a discriminação nas relações privadas, promovendo uma (ii) incidência do direito à igualdade de tratamento em casos isolados. Contudo, resta (iii) a discriminação como um princípio implícito do Direito Privado brasileiro, pois (iv) a proteção contra discriminação no contrato é uma exigência da autonomia privada, na medida em que a igualdade é um pressuposto para condições materiais de exercício da liberdade.

\section{REFERÊNCIAS}

BARCELLONA, Pietro. Diritto Privato e Società Moderna. Napoli: Jovene Editore, 1996.

BRASIL, Superior Tribunal de Justiça. Recurso Especial $n^{\circ}$ 809.329, Relator: Min. Nancy Andrighi, j. 25.03.2008. Disponível em: www.stj.gov.br. Acesso em: 17 ago 2013. BRASIL, Superior Tribunal de Justiça. Recurso Especial no 866.840, Relator: Min. Raul Araújo, j. 07.07.2011. Disponível em: www.stj.gov.br. Acesso em: 17 ago. 2013.

BRASIL, Superior Tribunal de Justiça. Recurso Especial no 911.802, Relator: Min. José Delgado, j. 24.10.2007. Disponível em: www.stj.gov.br. Acesso em: 17 ago. 2013.

BRASIL, Superior Tribunal de Justiça. Recurso Especial no 989.380, Relator: Min. Nancy Andrighi, j. 06.11.2008. Disponível em: www.stj.gov.br. Acesso em: 17 ago. 2013.

BRASIL, Superior Tribunal de Justiça. Recurso Especial $n^{\circ}$ 1.106.557, Relator: Min. Nancy Andrighi, j. 16.09.2010. Disponível em: www.stj.gov.br. Acesso em: 17 ago. 2013.

CANARIS, Claus-Wilhelm. Considerações a Respeito da Posição de Proibições de Discriminação no Sistema de Direito Privado. Revista Direitos Fundamentais \& Justiça. Porto Alegre: HS Editora, ano 7, nº 22, p. 15-20, jan./mar. 2013.

CARVALHO, Orlando de. Para uma Teoria da Relação Jurídica Civil. V. 1: A teoria geral da relação jurídica - seu sentido e limites. 2. ed., atual. Coimbra: Centelha, 1981.

CORTIANO JR., Eroulths. O Discurso Jurídico da Propriedade e suas Rupturas. Uma Análise do Ensino do Direito de Propriedade. Rio de Janeiro: Renovar, 2002.

FACHIN, Luiz Edson. Novo Conceito de Ato e Negócio Jurídico. Curitiba: Educa; Scientia et Labor, 1988.

FIGUEIRA, Eliseu. Renovação do Direito Privado. Lisboa: Caminho, 1989.

IRTI, Natalino. L'età della Decodificazione. 4. ed., Milano: Giuffrè, 1999.

LARENZ, Karl. Derecho Justo. Fundamentos de Etica Juridica. Trad.: Luis Díez-Picazo. Madrid: Editorial Civitas. 
LOUREIRO, Carlos Gabriel da Silva. Liberdade Contratual e Discriminação em Função do Sexo: a Lei $n^{\circ}$ 14/2008. Revista de Estudos Politécnicos, Barcelos, v. VIII, $\mathrm{n}^{\circ} 13$, p. 241-255, 2010, Disponível em: http://www.scielo.gpeari.mctes.pt/scielo.php?script= sci_serial\&pid=1645-9911\&lng=en. Acesso em: 05 ago. 2013.

MARQUES, Cláudia Lima. Contratos no Código de Defesa do Consumidor. 4. ed., v. 1, São Paulo: RT, 2002. p. 93.

MARTINS-COSTA, Judith. Reflexões sobre o Princípio da Função Social dos Contratos. Revista GVLaw. São Paulo, v. 1, no 1, p. 41-66, maio 2005, p. 45-47.

MODENESI, Pedro. Função Social dos Contratos: questões polêmicas na doutrina e na jurisprudência. Revista Trimestral de Direito Civil, Rio de Janeiro, v. 39, p. 185-208.

MORAES, Maria Celina Bodin de. Danos à Pessoa Humana: uma leitura civil-constitucional dos danos morais. Rio de Janeiro: Renovar, 2003.

MOTA PINTO, Paulo. Autonomia Privada e Discriminação: algumas notas. In: SARLET, Ingo Wolfgang (coord.). Constituição, Direitos Fundamentais e Direito Privado. Porto Alegre: Livraria do Advogado, 2006. p. 361-404.

NEUNER, Jôrg. O Princípio da Igualdade de Tratamento no Direito Privado Alemão. Revista Trimestral de Direito Civil, Rio de Janeiro, v. 37, p. 193-214, jan./mar. 2009.

NOVAIS, Jorge Reis. Contributo para uma Teoria do Estado de Direito. Do Estado de Direito liberal ao Estado Social e Democrático de Direito. Separata de: Suplemento ao Boletim da Faculdade de Direito da Universidade de Coimbra. Coimbra, v. 24, 1987.

PARANÁ, Tribunal de Justiça do Paraná. Apelação Cível nº 873.083-8, Relator: Des. Luiz Osório Moraes Panza, j. 03.07.2012. Disponível em: www.tjpr.jus.br. Acesso em: 12 ago. 2013.

PERLINGIERI, Pietro. /l Diritto Civille nella Legatlità Constituzionale. Napoli: Edizioni Scientifiche Italiane, 1991.

PERLINGIERI, Pietro. Perfis do Direito Civil. Introdução ao Direito Civil Constitucional. Tradução e Maria Cristina de Cicco. 3. ed., Rio de Janeiro: Renovar, 1997.

PRATA, Ana. A Tutela Constitucional da Autonomia Privada. Coimbra: Almedina, 1982.

RIO GRANDE DO SUL, Tribunal de Justiça do Rio Grande do Sul. Embargos Infringentes no 70030880603, Relator: Des. José Ataídes Siqueira Trindade, j. 14.08.2099. Disponível em: www.tjrs.jus.br. Acesso em: 15 ago. 2013.

ROMAIN, Jean-François. Théorie Citique du Principe Général de Bonne foi em Droit Privé. Des atteintes à la bonne foi, en général, et de la fraude, en particulier (fraus omnia corrumpit). Bruxelles: Bruylant, 2000.

ROPPO, Enzo. O Contrato. Tradução de Ana Coimbra e M. Januário C. Gomes. Coimbra: Almedina, 1988.

RUIZ, Francisco Infante. Igualdad, Diversidad y Protección contra la Discriminación en el Derecho Privado. In: MARRERO, Carolina Mesa (coord.). Mujeres, Contratos y Empresa desde la Igualdad de Género. Valencia: Tirant lo Blanch, 2013. p. 191-250.

El Desarrollo de la Prohibición de no Discriminar en el Derecho de Contratos y su Consideración en la Jurisprudencia. Revista de Derecho Patrimonial, Santiago de Chile, $n^{\circ}$ 30, jan. 2013, p. 1-30.

. La Protección contra la Discriminación mediante el Derecho Privado. InDret. Revista para el Análisis del Derecho. Barcelona, p. 2-17, abr. 2008. Disponível em: WWW.INDRET.COM. Acesso em: 05 ago. 2013. 
RULL, Ariadna Aguilera. Discriminación Directa e Indirecta. InDret. Revista para el Análisis del Derecho. Barcelona, p. 2-17, abr. 2008. Disponível em: WWW.INDRET.COM. Acesso em: 05 ago. 2013.

RULL, Ariadna Aguilera. Prohibición de Discriminación y Libertad de Contratación. InDret. Revista para el Análisis del Derecho, Barcelona, p. 2-30, fev. 2009. Disponível em: WWW.INDRET.COM. Acesso em: 05 ago. 2013.

SANTOS, Boaventura de Sousa. Por uma Concepção Multicultural de Direitos Humanos. In: BALDI, César Augusto. Direitos Humanos na Sociedade Cosmopolita. Rio de Janeiro: Renovar, 2004, p. 239-277.

SÃO PAULO, Tribunal de Justiça de São Paulo, Apelação Cível nº 0026182-80.2011.8. 26.0602, Relator: Des. Antonio Nascimento, j. 12.09.2012. Disponível em: www.tjsp.jus.br. Acesso em: 12 ago. 2013.

SARLET, Ingo Wolfgang. A Eficácia dos Direitos Fundamentais. 5. ed., Porto Alegre: Livraria do Advogado, 2005, p. 382-383.

SILVA, Jorge Cesa Ferreira da. A Proteção contra Discriminação no Direito Contratual Brasileiro. MONTEIRO, António Pinto; NEUNER, Jörg; SARLET, Ingo Wolfgang (org.). Direitos Fundamentais e Direito Privado. Uma Perspectiva de Direito Comparado. Coimbra: Almedina, 2007, p. 389-416.

STEINMETZ, Wilson. A Vinculação dos Particulares a Direitos Fundamentais. São Paulo: Malheiros, 2004.

TEPEDINO, Gustavo. As Relações de Consumo e a Nova Teoria Contratual. In: . Temas de Direito Civil. Rio de Janeiro: Renovar, 1999. p. 199-215. 